Received: September 16, 2015

\title{
The Short Form of the Five-Factor Narcissism Inventory: Psychometric Equivalence of the Turkish Version
}

\author{
Füsun Eksi ${ }^{1}$ \\ İstanbul Medeniyet University
}

\begin{abstract}
This study intends to examine the psychometric properties of the Turkish version of the short form of the Five-Factor Narcissism Inventory (FFNI-SF). The study group consists of a total of 526 university students ( $54 \%$ were female) whose ages range from 18 to 32 . In the translational equivalence study made over a two-week interval, the FFNI-SF scores showed high consistency. Cronbach's alpha was found to be .87 for the total score, and the alphas for the FFNI-SF subscales ranged from .57 to .79 . Corrected item-subscale correlations for the items ranged from .22 to .73. Confirmatory factor analysis results have shown that among the three competing models derived from the conceptual models, Model 1 with 15 factors had the best goodness-of-fit to the data, $\square^{2}=3851.48, \mathrm{df}=1605, \square^{2} / \mathrm{sd}=2.40, \mathrm{RMSEA}=.057, \mathrm{AGFI}=.74, \mathrm{GFI}=$ $.77, \mathrm{CFI}=.77, \mathrm{NNFI}=.75$. The correlation of total scores from the Narcissistic Personality Inventory (NPI) and FFNI-SF was $.65, p<.01$. Study results indicated that the Turkish version of the FFNI-SF may serve as a useful tool in assessing narcissistic personality traits in non-clinical samples.
\end{abstract}

Keywords

Narcissism • Personality $\bullet$ Big five $\bullet$ Five-factor model

1 Correspondence to: Füsun Ekși (PhD), Department of Educational Sciences, İstanbul Medeniyet University, Ünalan Mah. Ünalan Sok. D-100 Karayolu Yanyol Üsküdar İstanbul 34700 Turkey. Email: eksifusun@gmail.com

Citation: Eksi, F. (2016). The short form of the Five-Factor Narcissism Inventory: Psychometric equivalence of the Turkish version. Educational Sciences: Theory \& Practice, 16, 1081-1096. http://dx.doi.org/10.12738/estp.2016.4.0001 
Narcissism is named after Narcissus, a famous character from Greek mythology who was fated to fall in love with himself. Narcissism is an important and complex phenomenon studied in many subfields of psychology that include, but are not limited to, clinical (therapeutic), organizational, developmental, and social psychology (Sherman et al., 2015). Narcissism is characterized by grandiosity, arrogance, and a callous defense of one's self-image as perfect; interest in others is only a means for regulating self-esteem (Kubarych, Deary, \& Austin, 2004).

The narcissistic personality was first introduced as a psychological concept by Wälder (as cited in Campbell \& Miller, 2011). Freud saw narcissism as an unhealthy relationship between one's ego and libido, and he advanced the concept of narcissism by introducing the ego-libido personality type characterized by independence, extraversion, and an inability to commit to long-term relationships; yet narcissists usually attract attention and admiration, taking leadership roles (1991; 1950). Psychodynamic theoreticians such as Kernberg and Kohut are credited for making elaborate efforts at understanding and treating narcissistic personalities and establishing foundations for the Diagnostic and Statistical Manual of Mental Disorder's (DSM) criteria of narcissistic personality disorder (Campbell \& Miller, 2011). Kernberg (2004) envisioned narcissism as originating from a maladaptive pattern that originates in early childhood. On the other hand, Kohut $(1971 ; 1977)$ defined childhood narcissism and exhibitionism as normal. However, a failure in transforming narcissistic patterns into healthier ones creates a narcissistic personality disorder in the later stages of development. Within terms of the psychoanalytical structural model, Kernberg defined narcissism as a libidinal investment in the self (Kernberg, 2004).

Based on the predominantly psychodynamic literature, Narcissistic Personality Disorder (NPD) was first included in the 3rd Edition of the DSM (American Psychiatric Association [APA], 1980) and assessment instruments were subsequently developed. In a "text revision" of DSM-IV (DSM-IV-TR; APA, 2000) and earlier versions, NPD was mainly defined by categorical criteria. The DSM-IV-TR stressed narcissism of the grandiose type over the vulnerability type (Miller et al., 2013). In DSM-V (APA, 2013), narcissistic traits were introduced and incorporated into the NPD criteria (Few et al., 2013; Miller, Gentile, Wilson, \& Campbell, 2013).

\section{Subtypes}

Narcissism is usually conceptualized within a continuum that ranges from normal to maladaptive or pathological forms. The pathological form of narcissism is usually studied within the context of psychodynamic theories, while the normal form is studied more through empirical methods (Blais \& Little, 2010). Pathological narcissism has been insufficiently studied due to different reasons, the lack of psychometrically sound measures being foremost (Schoenleber, Roche, Wetzel, 
Pincus, \& Roberts, 2015). Scientific study of narcissism is seen as "fragmented and under-pursued" (Blais \& Little, 2010). Miller and Campbell (2010) asserted that the scientific understanding of pathological narcissism is predominantly speculative and lacks empirical support.

The normal, sub-clinical form (trait narcissism) is also a crucial construct in the study of personalities (Paulhus, 2001). Subclinical narcissism, subclinical psychopathy, and Machiavellianism have been defined as the dark triad. All of these traits are linked to emotional coldness, aggressiveness, deception, and self-promotion (Paulhus \& Williams, 2002). On the other hand, it has also been suggested that most people can exhibit narcissistic behaviors, with the claim that a moderate level of narcissism may in fact even contribute to success and better functioning (Kets de Vries \& Miller, 1985). Trait narcissism has been shown to predict a wide range of psychological phenomena in many studies from recent decades (Ames, Rose, \& Anderson, 2006).

Narcissism has been studied within subtype classifications rather than as a single construct. Many scholars advocate that there are at least two variations (subtypes) of pathological narcissism: grandiosity (the overt type) and vulnerability (the covert type; Campbell \& Miller, 2011; Miller et al., 2015; Sherman et al., 2015; Wink, 1991). The grandiose variation is defined by attention seeking, arrogance, grandiosity, little observable anxiety, and a sense of entitlement, whereas the covert type is characterized by hypersensitivity to others' evaluations, and by inhibition, observable distress, and outwardly modest behavior (Akhtar \& Thomson, 1982; Wink, 1991). These types may be so distinct that people characterized with vulnerable narcissism are characterized by self-esteem difficulties, attachment problems, and introversion, while those diagnosed with grandiose narcissism are associated with dominant and antagonistic interpersonal behaviors (Miller et al., 2015).

In a longitudinal study carried out by Twenge, Konrath, Foster, Campbell, and Bushman (2008), the narcissism scores of American undergraduate students were found to increase over a span of 25 years. On the other hand, in another longitudinal study by Trzesniewski, Donnellan, and Robins (2008), no significant difference was found in narcissism scores over a similar period. Using Trzesniewski et al.'s data, Twenge and Foster (2008) also showed that, although there was no cumulative difference, the effect was visible when data were analyzed separately for different ethnicities.

In one study, narcissism was found to be positively correlated with extraversion (Lee \& Ashton, 2005) Lootens (2010) found that agreeableness and perceptions of maternal and paternal authoritarianism were associated with narcissism. Narcissism is also characterized partly by an exaggerated and persistent concern over one's physical appearance (Vazire, Naumann, Rentfrow, \& Gosling, 2008). For instance, stylish and expensive clothes were found to be positively correlated with NPD. 
Organizational psychology scholars have also extensively studied the manifestation of narcissism at the organizational level, as well as the individual level. The growing prevalence of narcissism has increased the level of scholarly attention on its construct, manifestations, and outcomes (Rousseau \& Duchon, 2015). Narcissism has also been linked with the usage of social networking-sites. Walters and Horton (2015) found that Facebook-usage was positively related with narcissism, yet no relation was found when the pre-existing level of narcissism had been controlled. They concluded that their findings support the notion that people with narcissistic traits may have higher levels of Facebook-use, as opposed to the hypothesis that Facebook-use increases narcissism.

Peoples' personality traits and tendency to show consistent cognitive, behavioral, and affective patterns have long been central to personality research in psychology. The five-factor model (FFM) is a broad hierarchical classification of personality traits based on five basic traits: openness, conscientiousness, extraversion, agreeableness, and neuroticism (McCrae \& John, 1992). The FFM is also seen as a developed version of Goldberg's big-five model (1993), though FFM has achieved wider applications (Block, 2012). Openness (openness to experience) encompasses the richness, breadth, and depth of one's experiences, creativity, and novelty. Conscientiousness is mainly characterized by having qualities such as impulse control, competence, being goaloriented, and able to delay gratification. Extraversion encompasses qualities such as being active and energetic, sociable, expressive, and outgoing. Agreeableness represents mainly pro-social qualities such as forgiveness, trustfulness, and kindness. Neuroticism is contrasted with emotional stability and characterized by anxiousness, self-defeating patterns, vulnerability, and impulsiveness (McCrae \& John, 1992). The FFM structure has been shown to be valid across instruments, observers, genders, and cultures; it has endured across decades in longitudinal studies on adults (McCrae \& Costa, 2003; McCrae \& John, 1992; McCrae, 2002²). FFM is utilized in a wide range of applications by psychologists all over the world (McCrae, 2002).

The FFM has also been successfully applied in a study of personality disorders and narcissism. In their meta-analysis, Saulsman and Page (2004) discovered that FFM traits have meaningful and coherent interactions with personality disorders. High neuroticism and low agreeableness levels have been found in most personality disorders. Measurement models for personality disorders based on the FFM enable researchers and clinicians to precisely work with the distinct elements of disorders rather than the overall disorder (Widiger, Lynam, Miller, \& Oltmanns, 2012). The FiveFactor Narcissism Inventory (FFNI; Glover, Miller, Lynam, Crego, \& Widiger, 2012) is a self-report scale of 148 items for measuring personality components associated with narcissism within the framework of the five-factor personality model (McCrae \& Costa, 2003). Glover et al. (2012) validated a model of 15 five-factor traits that fall 
within the domains of vulnerable narcissism and grandiose narcissism. The FFNI was also validated in a study by Miller, Gentile, and Campbell (2013); it uses a 5-point Likert-type scale that ranges from 1 (strongly disagree) to 5 (strongly agree). Sherman et al. developed the short form of the FFNI (FFNI-SF; 2015). Double-entry intraclass correlations (ICC) indicated a high level of compatibility between the short form and the original form. The FFNI-SF consists of 45 items. The exploratory factor analysis results indicated that the three-factor solution for the FFNI-SF's original form explained $59 \%$ of the total variance. The aim of the present study is to investigate the properties of psychometric effectiveness for the Turkish version of the FFNI-SF.

\section{Method}

\section{Participants}

Participants of the study consisted of students from an urban state university. Data from 428 participants were utilized in the construct validity and reliability studies. Responses from another group of 62 participants were used in the concurrent validity study. In the translational equivalence study, data from 36 English teacher candidates were collected. The ages of the 526 (total) participants (54\% female) ranged from 18 to 32 . All participants were informed about the aims of the study, and confidentiality was ensured.

\section{Procedure}

The FFNI-SF was adapted into Turkish in the following sequential steps. Firstly, kind permission from Donald R. Lynamile, the corresponding author of the original FFNI-SF study, was requested and obtained for adapting the scale into Turkish. Then the FFNI-SF items were translated into Turkish by three academicians proficient in English and Turkish. A translation back to English was also conducted based on the translated Turkish forms. Changes and corrections on item wordings were done based on the compatibility between the original and Turkish forms by three academicians with degrees in relevant areas of psychology. The final Turkish form was created, and a translational equivalence check was made on a group of English teacher candidates who were proficient at speaking in both languages.

The reliability of the FFNI-SF was investigated by calculating the internal consistency coefficients and item-total correlations based on the subscales. Construct validity of the scale was tested through confirmatory factor analysis (CFA) and factor intercorrelations. Concurrent validity of the scale was investigated on a separate sample by calculating correlations among the scores from the FFNI-SF, Ten-Item Personality Inventory, and Narcissistic Personality Inventory. LISREL 8.51 and SPSS 17.0 software packages were utilized for these psychometric analyses. 


\section{Measures}

Ten-Item Personality Inventory (TIPI). TIPI is a 10 item-scale designed as a self-report measure for the big-five personality traits. The scale, which is composed of the subscales of openness, agreeableness, neuroticism, conscientiousness, and extraversion, was developed in accordance with the related literature by Gosling, Rentfrow, and Swann (2003). Each subscale has one positive and one negatively worded item for each respective trait. Responses are rated using a 7-point Likerttype scale. In the original study, internal consistency reliability coefficients for the scale ranged from .40 to .73 , and the test-retest reliability coefficients ranged from .72 to .80. TIPI was adapted into Turkish by Atak (2013); the internal consistency reliability coefficients for the scale ranged from .81 to .86 , and the test-retest reliability coefficients ranged from .87 to .89 . Through confirmatory factor analysis (CFA), the proposed five-factor model fit the data at acceptable levels, $X^{2} / \mathrm{sd}=2.20$, RMSEA = $.037, \mathrm{NNFI}=.91, \mathrm{CFI}=.93, \mathrm{GFI}=.95, \mathrm{AGFI}=.92, \mathrm{RMR}=.042$.

Narcissistic Personality Inventory (NPI). The NPI-40 is a scale composed of 40 items intended widely for use in measuring narcissistic personality traits (Atay, 2009). Ames, Rose, and Anderson (2006) created and validated a short form of the NPI-40, the NPI-16. It is a 16-item scale composed of six subscales: authority, exhibitionism, self-sufficiency, entitlement, exploitativeness, and superiority. The scale has a binary scoring system and two response options for each item; one alternative is a narcissistic response, and the other is a typical response. Respondents choose one sentence for each item. Narcissistic responses are scored as " 1 " and typical responses as " 0 ." The scores are totaled after compensating for reverse-scored items to calculate the subscale and total narcissism scores. In the adaptation study by Atay (2009), the percentage of total variance explained by the factors was $60.8 \%$; internal consistency coefficients were .57 for the first sample, and .65 for the second sample.

Five-Factor Narcissism Inventory-Short Form (FFNI-SF). FFNI-SF is the short form of the Five-Factor Narcissism Inventory (FFNI) developed by Glover et al. (2012). The FFNI is a 148-item self-report scale for measuring personality components associated with narcissism within the framework of the five-factor personality model (McCrae \& Costa, 2003). Glover et al. validated a model of 15 five-factor traits that fall within the domains of vulnerable narcissism and grandiose narcissism: acclaim-seeking, arrogance, authoritativeness, distrust, entitlement, exhibitionism, exploitativeness, grandiose fantasies, indifference, lack of empathy, manipulativeness, need for admiration, reactive anger, shame, and thrill-seeking. The scale uses a 5-point Likert-type scale ranging from 1 (strongly disagree) to 5 (strongly agree). Sherman et al. (2015) developed the short form of the FFNI, the FFNI-SF. Double-entry intraclass correlations (ICC) indicated high levels of compatibility between the short and original forms. Exploratory factor analysis results indicated that the three-factor solution of the original FFNI-SF explained $59 \%$ of the total variance. 


\section{Results}

\section{Translational Equivalence}

Translational equivalence of the Turkish and original forms of the scale was tested on a sample of 36 university students (English teacher candidates) who had Turkish as their native language and were fluent in English. The Pearson correlation coefficient between the total scores of the Turkish and English forms that were administered in a two-week interval was .99 $(p<.001)$.

\section{Reliability}

Internal consistency. Internal consistency of the scale was tested by calculating the alpha coefficients for the subscales and the overall scale. Alpha values for the subscales were .64 for acclaim-seeking, .60 for arrogance, .65 for authoritativeness, .57 for distrust, .74 for entitlement, .70 for exhibitionism, .79 for exploitativeness, .58 for grandiose fantasies, .74 for indifference, .69 for lack of empathy, .67 for manipulativeness, .56 for need for admiration, .63 for reactive anger, .76 for shame, and .75 for thrill-seeking. The alpha value calculated for the overall scale was .87 .

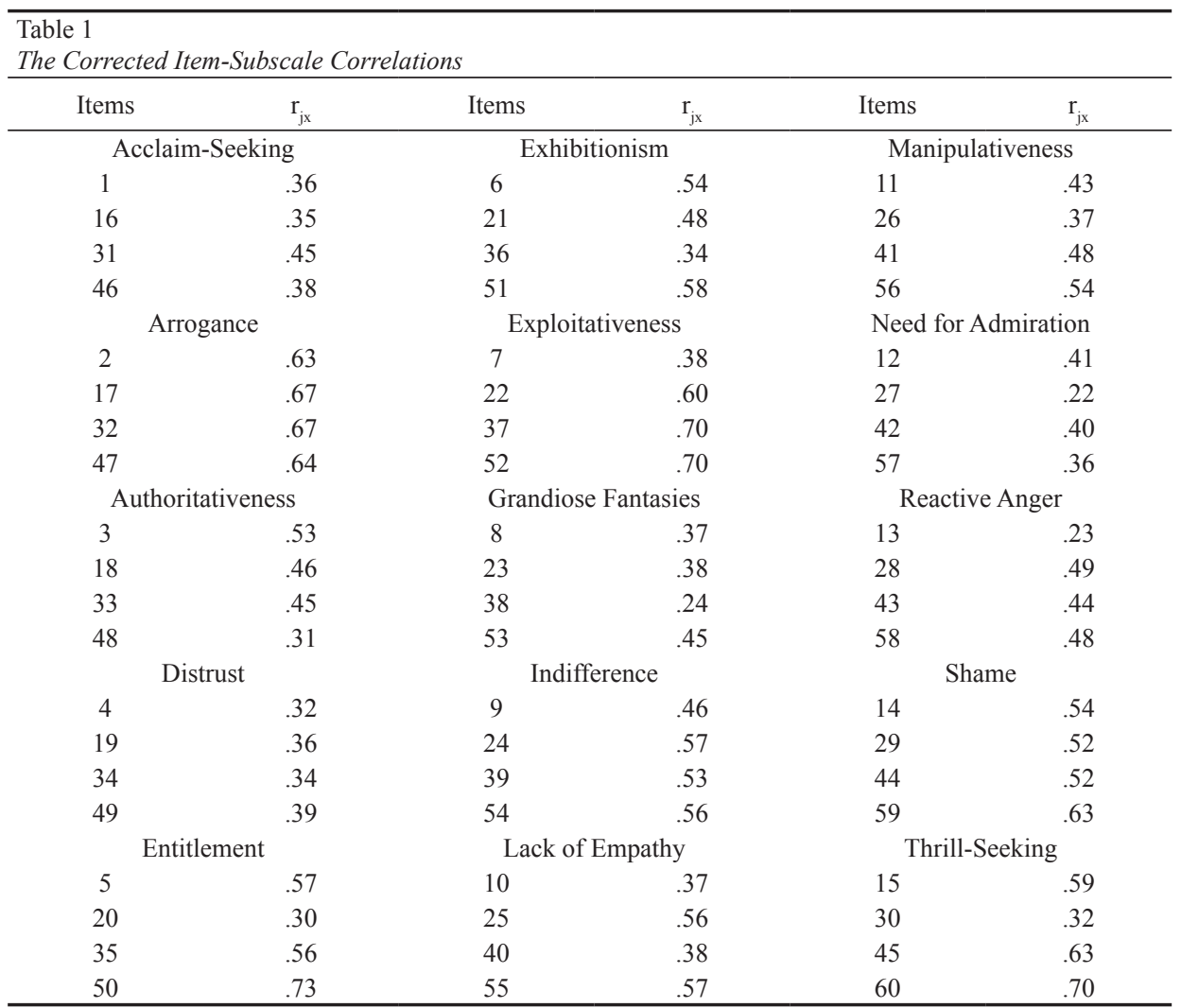

Note. All coefficients are at a significant level $(p<.001)$. 
Item-subscale correlations. Item-subscale correlations were calculated as an additional indicator for appraising the function of the items. Corrected item-subscale correlations for the items ranged from .22 to .73. Results are presented in Table 1.

\section{Validity}

Construct validity. Construct validity of the scale was tested through confirmatory factor analysis. Three alternative conceptual models derived from the original study (Sherman et al., 2015) were tested. Model 1 had 60 items loaded on 15 factors: acclaim-seeking, arrogance, authoritativeness, distrust, entitlement, exhibitionism, exploitativeness, grandiose fantasies, indifference, lack of empathy, manipulativeness, need for admiration, reactive anger, shame, and thrill-seeking (denoted as var1-var15 in Figure 1, respectively). Model 2 had 60 item-loadings on the same 15 factors plus one higher-order factor (narcissism). Model 3 had 60 items loaded on 15 factors plus two higher-order factors (grandiose and vulnerability). The models were tested without defining any covariance errors between the items or subscales. The results of CFA showed that among the three models, Model 1 had the best data fit, $\square^{2}=$ $3851.48, d f=1605, \square^{2} / s d=2.40, \mathrm{RMSEA}=.057, \mathrm{AGFI}=.74, \mathrm{GFI}=.77, \mathrm{CFI}=.77$, NNFI $=.75$. The goodness-of-fit statistics for the three models are presented in Table 2. For Model 1, factor loadings $(\square)$ ranged from .27 to .83 , and $t$-values ranged from 4.97 to 18.69 , all of which were statistically significant. The path diagram for Model 1 is presented in Figure 1.

\begin{tabular}{|c|c|c|c|c|c|c|c|c|}
\hline \multicolumn{9}{|c|}{$\begin{array}{l}\text { Table } 2 \\
\text { Goodness-of-fit Statistics for the Three Models }\end{array}$} \\
\hline Models $^{1}$ & $\square^{2}$ & $s d$ & $\square^{2} / s d$ & RMSEA & AGFI & GFI & CFI & NNFI (TLI) \\
\hline Model 1 & 3851.48 & 1605 & 2.40 & .057 & .074 & .77 & .77 & .75 \\
\hline Model 2 & 5361.80 & 1695 & 3.16 & .071 & .068 & .70 & .68 & .67 \\
\hline Model 3 & 5059.99 & 1694 & 2.99 & .068 & .069 & .72 & .70 & .69 \\
\hline
\end{tabular}

Factor intercorrelations were calculated as another method for testing the factor structure. As indicated by the CFA results, the best-fit model was the model with 15 factors. The subscales' low-to-moderate correlations were consistent with the CFA findings. Pearson's correlation coefficients are presented in Table 3. In the table, S1-S15 respectively denote the following subscales: acclaim-seeking, arrogance, authoritativeness, distrust, entitlement, exhibitionism, exploitativeness, grandiose fantasies, indifference, lack of empathy, manipulativeness, need for admiration, reactive anger, shame, and thrill-seeking. 


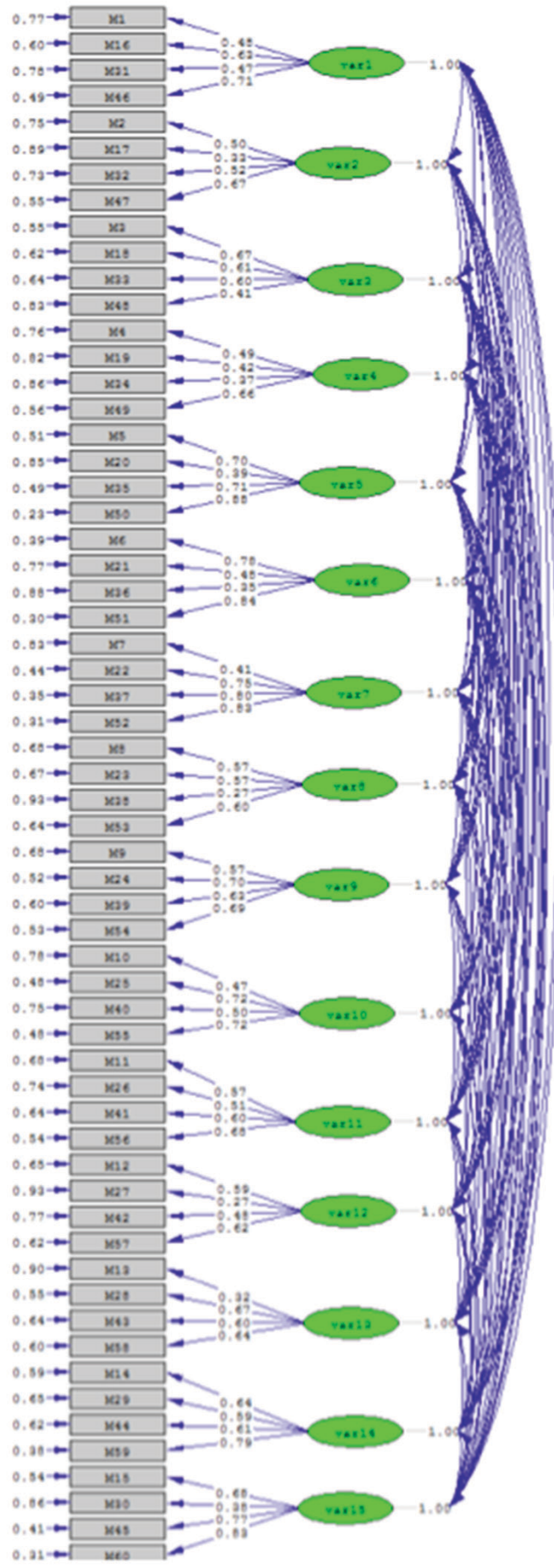

Chi-Square $=3851.48, \mathrm{df}=1605, \mathrm{p}-\mathrm{value}=0.00000, \mathrm{RMSEA}=0.057$

Figure 1. Factor Loadings and Path Diagram for the FFNI-SF. 
Table 3

Factor Intercorrelations

\begin{tabular}{|c|c|c|c|c|c|c|c|c|c|c|c|c|c|c|c|}
\hline \multirow{2}{*}{$S 1$} & S1 & $S 2$ & S3 & S4 & S5 & S6 & S7 & S8 & S9 & $S 10$ & S11 & $S 12$ & $S 13$ & S14 & $S 15$ \\
\hline & & & & & & & & & & & & & & & \\
\hline$S 2$ & $.31^{* *}$ & & & & & & & & & & & & & & \\
\hline S3 & $.39^{* *}$ & $.25^{* *}$ & & & & & & & & & & & & & \\
\hline S4 & $.14^{* *}$ & $.27^{* * *}$ & 0.08 & & & & & & & & & & & & \\
\hline S5 & $.23^{* *}$ & $.54^{* * *}$ & $.20^{* * *}$ & $.20^{* * *}$ & & & & & & & & & & & \\
\hline S6 & $.31^{* *}$ & $.12^{*}$ & $.24^{* *}$ & $.10^{*}$ & $.27^{* *}$ & & & & & & & & & & \\
\hline S7 & $.21^{* *}$ & $.37^{* *}$ & $.14^{* *}$ & $.19^{* * *}$ & $.44^{* *}$ & $.21^{* *}$ & & & & & & & & & \\
\hline 58 & $.48^{* *}$ & $.31^{* *}$ & $.22^{* * *}$ & $.20^{* * *}$ & $.36^{* *}$ & $.35^{* *}$ & $.40^{* * *}$ & & & & & & & & \\
\hline 59 & 0.03 & $.19^{* * *}$ & $.15^{* *}$ & $.11^{*}$ & $.12^{*}$ & $-.10^{*}$ & $.16^{* *}$ & -0.01 & & & & & & & \\
\hline$S 10$ & 0.01 & $.38^{* *}$ & -0.03 & $.19^{* * *}$ & $.33^{* * *}$ & $-.19^{* * *}$ & $.30^{* * *}$ & $.12^{*}$ & $.30^{* * *}$ & & & & & & \\
\hline$S 11$ & $.34^{* *}$ & $.39^{* *}$ & $.49^{* *}$ & $.19^{* *}$ & $.43^{* *}$ & $.25^{* *}$ & $.39^{* *}$ & $.33^{* *}$ & $.23^{* *}$ & $.19^{* *}$ & & & & & \\
\hline$S 12$ & $-.22^{* * *}$ & -0.03 & $-.37^{* *}$ & $.12^{*}$ & $.12^{*}$ & 0.07 & 0.06 & 0.06 & $-.30^{* *}$ & 0.06 & $-.17^{* *}$ & & & & \\
\hline$S 13$ & $.19^{* *}$ & $.20^{* *}$ & 0.04 & $.31^{* *}$ & $.33^{* * *}$ & $.28^{* *}$ & $.20^{* * *}$ & $.30^{* * *}$ & $-.11^{*}$ & 0.04 & $.19^{* *}$ & $.24^{* * *}$ & & & \\
\hline 514 & 0.08 & $.12^{*}$ & $-.23^{* *}$ & $.13^{* *}$ & $.21^{* *}$ & $.21^{* * *}$ & 0.09 & $.18^{* * *}$ & $-.28^{* *}$ & 0.04 & -0.06 & $.50^{* * *}$ & $.36^{* * *}$ & & \\
\hline$S 15$ & $.22^{* * *}$ & $.31^{* *}$ & $.23^{* * *}$ & $.14^{* * *}$ & $.32^{* * *}$ & $.23^{* *}$ & $.22^{* *}$ & $.25^{* * *}$ & $.18^{* *}$ & $.15^{* *}$ & $.31^{* * *}$ & -0.08 & $.18^{* *}$ & 0.02 & \\
\hline
\end{tabular}

* Correlation is significant at $p<0.05$ (2-tailed).

$* *$ Correlation is significant at $p<0.01$ (2-tailed).

Concurrent validity. The correlations of total scores of the Narcissistic Personality Inventory (NPI), FFNI-SF, and Ten-Item Personality Inventory (TIPI) based on the big-five personality traits were calculated as an index for concurrent validity. Because the skewness and kurtosis values of the scales exceeded the acceptable range for two variables, Spearman's non-parametric correlation coefficients were preferred. The correlation of the total scores from the NPI and FFNI-SF was .65 $(p<.01)$. The results are presented in Table 4.

Table 4

Correlations of FFNI-SF, NPI Scores and TIPI Subscales

\begin{tabular}{|c|c|c|c|c|c|c|c|}
\hline & 1 & 2 & 3 & 4 & 5 & 6 & 7 \\
\hline \multicolumn{8}{|l|}{ 1. FFNI-SF } \\
\hline 2. NPI & $.65^{* *}$ & & & & & & \\
\hline 3. Openness & -.00 & -.11 & & & & & \\
\hline 4. Agreeableness & -.01 & -.16 & .04 & & & & \\
\hline 5. Neuroticism & -.07 & -.05 & $-.30^{*}$ & $.28^{*}$ & & & \\
\hline 6. Conscientiousness & -.09 & -.11 & $.27^{*}$ & .19 & $.27^{*}$ & & \\
\hline 7. Extraversion & .14 & .17 & .14 & -.13 & .11 & .12 & \\
\hline Mean & 174.77 & 7.24 & 7.71 & 7.15 & 6.02 & 8.15 & 6.82 \\
\hline Std. Dev. & 21.67 & 7.07 & 1.58 & 1.52 & 2.15 & 1.62 & 2.08 \\
\hline
\end{tabular}

* Correlation is significant at $p<.05$ (2-tailed).

** Correlation is significant at $p<.01$ (2-tailed).

\section{Discussion}

The objective of the present study was to investigate the properties of psychometric effectiveness for the Turkish version of the FFNI-SF. Linguistic-equivalence study results indicated that the Turkish form had high levels of compatibility with the original FFNI-SF 
form. Internal consistency coefficients were at adequate levels for the subscales and for the total scale (Kline, 2000). Item-total correlations based on the subscales as indexes for item-functioning were at acceptable levels (Büyüköztürk, 2010).

CFA was utilized for assessing the construct validity levels of the scale. RMSEA values should be between .050 and .080 for acceptable levels of fit, and below .050 for perfect levels of fit to the data (Brown \& Cudeck, 1993; Byrne \& Campbell, 1999). $X^{2} / \mathrm{sd}$ values in the 2-3 interval indicate acceptable fit to the data, and values in the 0-2 interval indicate perfect levels of fit (Schermelleh-Engel \& Moosbrugger, 2003). The threshold for GFI, CFI, and NNFI fit-indexes is .90 for acceptable levels of fit, and .95 or higher for perfect fit (Hu \& Bentler, 1999; Marsh, Hau, Artelt, Baumert, \& Peschar, 2006).

The models were derived from the original study of Sherman et al. (2015). According to the CFA results, the model with 60 items and 15 factor-loadings fit the data best (Model 1). Models 2 and 3, each with 15 factors (plus one higher-order factor of narcissism for Model 2 and two higher-order factors of grandiose and vulnerable for Model 3) also had acceptable levels of fit to the data. Although the three models had acceptable levels of fit with regard to the $X^{2} /$ sd value, which is regarded as the most robust criteria for CFA and SEM in general, GFI, CFI, and NNFI were lower than acceptable levels. This may be regarded as a limitation of our findings. On the other hand, researchers have also found that fit indexes such as GFI, CFI, and NNFI are negatively affected by sample size, especially in large samples (Bollen, 1990). The factor intercorrelations indicated that the subscales had distinct characteristics.

The correlation between the FFNI-SF and NPI scores supported the concurrent validity of the FFNI-SF Turkish form. No significant relationships between the FFNI-SF and BigFive Personality Trait scores were obtained from the TIPI. In the original study (Sherman et al., 2015), low yet significant relationships were found in the undergraduate sample, and moderate-to-high correlations were found in the clinical sample.

The psychometric findings indicate that the Turkish FFNI-SF has acceptable reliability and validity levels, and is ready for use in Turkish samples. It is also important to note that this Turkish version of the scale was only validated on an undergraduate sample; further studies should focus on validating the scale on clinical samples.

\section{References}

Akhtar, S., \& Thomson, J. A. (1982). Overview: Narcissistic personality disorder. American Journal of Psychiatry, 139, 12-20.

American Psychiatric Association. (1980). Diagnostic and statistical manual of mental disorders (3rd ed., DSM-III). Washington, DC: Author.

American Psychiatric Association. (2000). Diagnostic and statistical manual of mental disorders (4th ed., text rev.). Washington, DC: Author. 
American Psychiatric Association. (2013). Diagnostic and statistical manual of mental disorders (5th ed.). Washington, DC: Author.

Ames, D. R., Rose, P., \& Anderson, P. C. (2006), The NPI-16 as a short measure of narcissism, Journal of Research in Personality, 40, 440-450.

Atak, H. (2013). The Turkish adaptation of the 10-Item Personality Inventory. Archives of Neuropsychiatry, 50(4), 312-319.

Atay, S. (2009). Narsistik Kişilik Envanteri'nin Türkçe’ye standardizasyonu [Standardization of the Narcissistic Personality Inventory to Turkish]. Gazi Üniversitesi İktisadi ve İdari Bilimler Fakültesi Dergisi, 11(1), 181-196.

Blais, M. A., \& Little, J. A. (2010). Toward an integrative study of narcissism. Personality Disorders, 1(3), 197-199.

Block, J. (2010). The five-factor framing of personality and beyond: Some ruminations. Psychological Inquiry, 21, 2-25. http://dx.doi.org/10.1080/10478401003596626

Bollen, K. A. (1990). Overall fit in covariance structure models: Two types of sample size effects. Psychological Bulletin, 107(2), 256-259.

Brown, M., \& Cudeck, R. (1993). Alternative ways of assessing model fit. In K. A. Bollen \& J. S. Long (Eds.), Testing structural equation models (pp. 136-162). Beverly Hills, CA: Sage.

Büyüköztürk, Ş. (2010). Sosyal bilimler için veri analizi el kitabı [Data analysis handbook for social sciences]. (11th ed.). Ankara, Turkey: Pegem Akademi Yayınları.

Byrne, B. M., \& Campbell, T. L. (1999). Cross-cultural comparisons and the presumption of equivalent measurement and theoretical structure: a look beneath the surface. Journal of Cross-Cultural Psychology, 30, 555-574.

Campbell, W. K., \& Miller, J. D. (2011). The handbook of narcissism and narcissistic personality disorder. New York, NY: Wiley.

Few, L. R., Miller, J. D., Rothbaum, A. O., Meller, S., Maples, J., Terry, D. P., . . MacKillop, J. (2013). Examination of the Section III DSM-5 diagnostic system for personality disorders in an outpatient clinical sample. Journal of Abnormal Psychology, 122(4), 1057-1069.

Freud, S. (1991). On narcissism: An introduction. In J. Sandler, E. Person, \& P. Fonagy (Eds.), Freud's “On narcissism: An introduction”. New Haven, CT: Yale University Press. (Original work published 1914)

Freud, S. (1950). Libidinal types. In J. Strachey (Ed. and Trans.) The standard edition of the complete psychological works of Sigmund Freud (Vol. 21, pp. 217-220). London, England: Hogarth Press. (Original work published 1931)

Glover, N., Miller, J. D., Lynam, D. R., Crego, C., \& Widiger, T. A. (2012). The Five-Factor Narcissism Inventory: A five-factor measure of narcissistic personality traits. Journal of Personality Assessment, 94, 500-512. http://dx.doi.org/10.1080/00223891.2012.670680

Goldberg, L. R. (1993). The structure of phenotypic personality traits. American Psychologist, $48,26-34$.

Gosling S. D., Rentfrow, P. J., \& Swann, W. B. (2003). A very brief measure of the big-five personality domains. Journal of Research in Personality, 37, 504-528.

Hu, L. T., \& Bentler, P. M. (1999). Cutoff criteria for fit indexes in covariance structural analysis: Conventional criteria versus new alternatives. Structural Equation Modeling, 6, 1-55.

Kernberg, O. F. (2004). Aggressivity, narcissism, and self-destructiveness in the psychotherapeutic relationship: New developments in the psychopathology and psychotherapy of severe personality disorders. New Haven, CT: Yale University Press. 
Kets de Vries, M. F. R., \& Miller, D. (1985a). Narcissism and leadership: An object relations perspective. Human Relations, 38, 583-601.

Kline, P. (2000). Handbook of psychological testing (2nd ed.). London, UK: Routledge.

Kohut, H. (1971). The analysis of the self. New York, NY: International University Press.

Kohut, H. (1977). Restoration of the self. New York, NY: International University Press.

Kubarych, T. S., Deary, I. J., \& Austin, E. J. (2004). The Narcissistic Personality Inventory: Factor structure in a non-clinical sample. Personality and Individual Differences, 36, 857-872.

Lee, K., \& Ashton, M. C. (2005). Psychopathy, Machiavellianism, and narcissism in the fivefactor model and the HEXACO model of personality structure. Personality and Individual Differences, 38(7), 1571-1582.

Lootens, C. M. (2010). An examination of the relationships among personality traits, perceived parenting styles, and narcissism (Doctoral dissertation). The Graduate School at the University of North Carolina. Greensboro, NC.

Marsh, H. W., Hau, K. T., Artelt, C., Baumert, J., \& Peschar, J. L. (2006). OECD's brief self-report measure of educational psychology's most useful affective constructs: Crosscultural, psychometric comparisons across 25 countries. International Journal of Testing, 6(4), 311-360.

McCrae, R. R. (2002). Cross-cultural research on the five-factor model of personality. Online Readings in Psychology and Culture, 4(4). http://dx.doi.org/10.9707/2307-0919.1038

McCrae, R. R., \& Costa, P. T. (2003). Personality in adulthood: A five-factor theory perspective (2nd ed.). New York, NY: Guilford Press. http://dx.doi.org/10.4324/9780203428412

McCrae, R. R., \& John, O. P. (1992). An introduction to the five-factor model and its applications. Journal of Personality, 60, 175-215. http://dx.doi.org/10.1111/j.1467-6494.1992.tb00970.x

Miller, J. D., \& Campbell, W. K. (2010). The case for using research on trait narcissism as a building block for understanding narcissistic personality disorder. Personality Disorders: Theory, Research, and Treatment, 1, 180-191.

Miller, J. D., Gentile, B., \& Campbell, W. K. (2013). A test of the construct validity of the Five-Factor Narcissism Inventory. Journal of Personality Assessment, 95, 377-387, http:// dx.doi.org/10.1080/00223891.2012.742903

Miller, J. D., Gentile, B., Wilson, L., \& Campbell, W. K. (2013). Grandiose and vulnerable narcissism and the DSM-5 pathological personality trait model. Journal of Personality Assessment, 95(3), 284-290.

Miller, J. D., Lynam, D. R., McCain, J. L., Few, L. R., Crego, C., Widiger, T. A., \& Campbell, W. K. (2015). Thinking structurally about narcissism: An examination of the Five-Factor Narcissism Inventory and its components. Journal of Personality Disorders, 29, 177-194.

Paulhus, D. L. (2001). Normal narcissism: Two minimalist accounts. Psychological Inquiry, 12(4), 228-230.

Paulhus, D. L., \& Williams, K. M. (2002). The dark triad of personality: Narcissism, Machiavellianism, and psychopathy. Journal of Research in Personality, 36, 556-563. http://dx.doi.org/10.1016/S0092-6566(02)00505-6

Rousseau, B. M., \& Duchon, D. (2015). Organizational narcissism: Scale development and firm outcomes. Journal of Organizational Culture, Communications and Conflict, 19(1), 159-175.

Saulsman, L. M., \& Page, A. C. (2004). The five-factor model and personality disorder empirical literature: A meta-analytic review. Clinical Psychology Review, 23(8), 1055-1085. 
Schermelleh-Engel, K., \& Moosbrugger, H. (2003). Evaluating the fit of structural equation models: Tests of significance and descriptive goodness-of-fit measures. Methods of Psychological Research Online, 8(2), 23-74.

Schoenleber, M., Roche, M. J., Wetzel, E., Pincus, A. L., \& Roberts, B. W. (2015). Development of a brief version of the Pathological Narcissism Inventory. Psychological Assessment, 27(4), 1520-1526.

Sherman, E. D., Miller, J. D., Few, L. R., Campbell, W. K., Widiger, T. A., Crego, C., \& Lynam, D. R. (2015). Development of a short form of the Five-Factor Narcissism Inventory: The FFNISF. Psychological Assessment, 27(3), 1110-1116. http://dx.doi.org/10.1037/pas0000100

Trzesniewski, K. H., Donnellan, M. B., \& Robins, R. W. (2008). Do today's young people really think they are so extraordinary? An examination of secular changes in narcissism and self-enhancement. Psychological Science, 19, 181-188.

Twenge, J. M., \& Foster, J. D. (2008). Mapping the scale of the narcissism epidemic: Increases in narcissism 2002-2007 within ethnic groups. Journal of Research in Personality, 42(6), 1619-1622. http://dx.doi.org/10.1016/j.jrp.2008.06.014

Twenge, J. M., Konrath, S., Foster, J. D., Campbell, W. K., \& Bushman, B. J. (2008). Egos inflating over time: A cross-temporal meta-analysis of the Narcissistic Personality Inventory. Journal of Personality, 76, 875-901.

Vazire, S., Naumann, L. P., Rentfrow, P. J., \& Gosling, S. D. (2008). Portrait of a narcissist: Manifestations of narcissism in physical appearance. Journal of Research in Personality, 42(6), 1439-1447.

Walters, N. T., \& Horton, R. (2015). A diary study of the influence of Facebook use on narcissism among male college students. Computers in Human Behavior, 52, 326-330.

Widiger, T. A., Lynam, D. R., Miller, J. D., \& Oltmanns, T. F. (2012). Measures to assess maladaptive variants of the five-factor model. Journal of Personality Assessment, 94, 450-455.

Wink, P. (1991). Two faces of narcissism. Journal of Personality and Social Psychology, 61, 590-597. 


\section{Appendix}

Beş Faktör Narsisizm Ölçeği-Kısa Form

1. Aşırı hırslı biriyimdir.

2. Başkaları çok övündügümü söylerler ama söylediğim her şey doğrudur.

3. Liderlik yapmak benim için kolaydır.

4. Birileri bana iyilik yaptığında, acaba benden ne istiyorlar diye merak ederim.

5. Özel muamele görmeyi hak ediyorum.

6. Başkalarını eğlendirmekten büyük zevk alırım.

7. İlerlemek için insanlardan yararlanmak iyi bir şeydir.

8. S1klıkla ünlü olmak ile ilgili hayaller kurarım.

9. İnsanlar beni yargıladığında, bunu hiç umursamam.

10. Başkalarının ihtiyaçlarını konusunda kaygılanmam.

11. İnsanları manipüle etmede /kullanmada oldukça iyiyimdir.

12. Kendimden emin olmak için sık sık başkalarının iltifatlarına ihtiyacın varmış gibi hissederim.

13. Eleştirilmekten, o kadar nefret ederim ki, olduğunda öfkemi kontrol edemem.

14. Bir şeyde başarısız olduğumu fark ettiğimde kendimi küçük düşmüş hissederim.

15. Heyecan duymak için neredeyse her şeyi deneyebilirim.

16. Başarılı olmak için inanılmaz bir motivasyonuna sahibim.

17. Sadece kendi ayarımdaki insanlarla ilişki kurarım.

18. Otorite pozisyonu alma konusunda kendimi rahat hissederim.

19. Diğer insanların bana karşı dürüst olacaklarına inanırım.

20. Kuralların başkaları için geçerli olduğu kadar benim için geçerli olduğunu düşünmüyorum.

21. Başkaları tarafından fark edilmekten hoşlanırım.

22. Kendi ilerlemem için insanları birer araç olarak kullanırım.

23. Sık sık çok başarılı ve güçlü olacağıma dair hayaller kurarım.

24. Başkalarının benim hakkımda ne düşündüğü gerçekten umursamam.

25. Başkalarının dertlerini genelde fazla ilgi göstermem.

26. İnsanları bir şeyler yaptırmak için yönlendirebilirim.

27. Benlik duygum istikrarlıdır.

28. Doğru muamele görmediğimde aşırı öfkelendiğim zamanlar olmuştur.

29. Başkalarının önünde küçük düşürüldüğümde berbat hissederim.

30. Gözü pek biriyimdir.

31. Büyük biri olmayı arzularım.

32. Benden daha aşağı kişilerle takılarak zamanımı boşa harcamam.

33. İnsanlar genellikle benim liderliğimi ve otoritemi takip ederler. 
34. İnsanlara güvenme konusunda temkinliyimdir.

35. Adaletsiz gibi gözükebilir ancak ihtimam, imtiyaz ve ödül gibi ayrıcalıkları hak ediyorum.

36. Bir parti ya da toplantıda en popüler kişi olmaktan hoşlanırım.

37. Başarıya ulaşmak için bazen diğer insanları kullanmanız gerekir.

38. Başarısıyla tanınmış biri olmayı nadiren hayal ederim.

39. Başkalarının eleştirilerine karşı oldukça kayıtsızımdır.

40. Sempati duygum zayıftır.

41. Eninde sonunda benim dediğim olur.

42. Hayatta yeterince başarıya ulaşıp ulaşamayacağım hakkında kendimi oldukça güvensiz hissederim.

43. Hak ettiğim şeyi alamamak beni gerçekten çok öfkelendirir.

44. İnsanlar beni yargıladığında utanırım.

45. Heyecan verici bir şey yapmak için yaralanmayı göze alabilirim.

46. Başarılı olmaya motiveyimdir.

47. Üstün bir insanım.

48. Çoğu durumda sorumluluk almaya eğilimliyimdir.

49. Sık sık diğerlerinin bana gerçeğin tamamını söylemediğini düşünürüm.

50. Özel muamele görmeyi hak ettiğime inanırım.

51. İnsanları eğlendirmeye bayılırım.

52. Kendi hedeflerime ulaşmada diğerlerini kullanmaya istekliyimdir

53. Bir gün benim adımı insanların çoğunun bileceğine inanıyorum.

54. Başkalarının benim hakkımdaki görüşlerini çok az umurumdadır.

55. Başkalarının acıları beni üzmez.

56. İnsanlara istediklerimi yaptırmam kolaydır.

57. Keşke başkalarının benim hakkımdaki düşüncelerini bu kadar umurumda olmasaydı

58. İnsanlar bana saygısızlık ettiğinde tepem atar.

59. Başkalarının önünde bir hata yaparsam kendimi aptal gibi hissederim.

60. Riskli ya da tehlikeli şeyler yapmaktan hoşlanırım. 